\title{
Transgenic Rabbit Models: Now and the Future
}

\author{
Fumikazu Matsuhisa ${ }^{1}$, Shuji Kitajima ${ }^{1, *} \mathbb{0}$, Kazutoshi Nishijima ${ }^{2}$, Toshiaki Akiyoshi ${ }^{1}$, \\ Masatoshi Morimoto ${ }^{1}$ and Jianglin Fan ${ }^{3}$ \\ 1 Division of Biological Resources and Development, Analytical Research Center for Experimental Sciences, \\ Saga University, 5-1-1 Nabeshima, Saga 849-8501, Japan; matsuf@cc.saga-u.ac.jp (F.M.); \\ imuha.stone55@hotmail.co.jp (T.A.); mm2430momochi@yahoo.co.jp (M.M.) \\ 2 Center for Animal Resources and Collaborative Study, National Institutes of Natural Sciences, \\ 38 Nishigonaka, Myodaiji, Okazaki, Aichi 444-8585, Japan; kanish@nips.ac.jp \\ 3 Department of Molecular Pathology, Faculty of Medicine, Graduate School of Medical Sciences, \\ University of Yamanashi, 1110 Shimokato, Chuo 409-3898, Japan; jianglin@yamanashi.ac.jp \\ * Correspondence: kitajims@cc.saga-u.ac.jp; Tel.: +81-952-34-2430
}

Received: 29 September 2020; Accepted: 20 October 2020; Published: 22 October 2020

check for updates

\begin{abstract}
Transgenic rabbits have contributed to the progress of biomedical science as human disease models because of their unique features, such as the lipid metabolism system similar to humans and medium body size that facilitates handling and experimental manipulation. In fact, many useful transgenic rabbits have been generated and used in research fields such as lipid metabolism and atherosclerosis, cardiac failure, immunology, and oncogenesis. However, there have been long-term problems, namely that the transgenic efficiency when using pronuclear microinjection is low compared with transgenic mice and production of knockout rabbits is impossible owing to the lack of embryonic stem cells for gene targeting in rabbits. Despite these limitations, the emergence of novel genome editing technology has changed the production of genetically modified animals including the rabbit. We are finally able to produce both transgenic and knockout rabbit models to analyze gain- and loss-of-functions of specific genes. It is expected that the use of genetically modified rabbits will extend to various research fields. In this review, we describe the unique features of rabbits as laboratory animals, the current status of their development and use, and future perspectives of transgenic rabbit models for human diseases.
\end{abstract}

Keywords: transgenic rabbits; genetically modified rabbits; rabbit models for human diseases; pronuclear microinjection; genome editing technology

\section{Introduction}

Genetically modified animals can be very useful tools for biomedical research. They are defined animals whose DNA has been altered using genetic engineering techniques, which include transgenic (carrying exogenous gene), knockout (disrupted endogenous gene by gene targeting), and knock-in (inserted gene sequence at a particular locus by gene targeting). Since the first birth of a transgenic mouse produced by pronuclear microinjection in 1980 [1], numerous genetically modified animals have been generated. In the biomedical research field, the mouse is the most used species for genetic modifications because of well-developed genetic engineering techniques that can produce not only transgenic, but also knockout animals by gene targeting techniques using embryonic stem (ES) cells [2]. In fact, various genetically modified murine models have been produced, which have strongly contributed to the progress of biomedical science. The mouse is one of the most useful laboratory animals, but it may not be omnipotent. Some physiological features of mice are quite different from those of humans, such as lipid metabolism [3-5]. Therefore, the mouse may not be suitable for research of lipid metabolism and atherosclerosis. To extrapolate findings from animal experimentation to 
humans, it is essential to choose an appropriate species that conforms to the purpose of the study. Therefore, the development of genetically modified non-murine models has been desired in several research fields where the mouse is considered as unsuitable.

In 1985, the first production of a transgenic rabbit was reported by Hammer et al. [6]. To date, many transgenic rabbits have been generated and used as both human disease models and bioreactors that produce valuable physiologically active substances in their milk [3,4,7-10]. However, in comparison with mice, the transgenic efficiency when using pronuclear microinjection is low and the production of knockout rabbits is difficult because ES cells have not been established for gene targeting in the rabbit $[8,11]$. These problems limit the use of genetically modified rabbits as human disease models. Therefore, studies to improve the productive efficiency of transgenic rabbits [12-16] and establish rabbit ES cells $[17,18]$ have been conducted for a long time. The emergence of novel genome editing technology such as Zinc finger nuclease (ZNF), transcription activator-like effector nuclease (TALEN), and clustered regularly interspaced short palindromic repeats (CRISPR)/CRISPR-associated protein 9 (Cas9), have changed production of genetically modified animals including the rabbit [19-21]. These techniques have revolutionized gene engineering technology because knockout animals can be produced easily with high efficiency by these techniques without ES cells. The first knockout rabbit generated by genome editing technology using ZFN was reported in 2011 [19]. After production of a knockout rabbit by the CRISPR/Cas9 system in 2014 [21], the number of reports of knockout rabbits for human disease models has increased rapidly [20,22-27]. The use of genetically modified rabbits will expand to various purposes in biomedical research, although they have been limited to only transgenic use for a long time.

Transgenic rabbits as human disease models have shown utility in several research fields in which the mouse is unsuitable as a model animal or as a superior model to the mouse, and they fulfill the need for a medium-sized animal between small rodents to humans for translational research. In this review, we introduce the unique features of the rabbit as a laboratory animal, the current status of their development and use, and future perspectives of transgenic rabbit models for human diseases.

\section{General Features of the Laboratory Rabbits}

The origin of laboratory rabbits is domesticated from wild rabbits (Oryctolagus cuniculus) that inhabited the Iberia district of the Mediterranean Sea coast. The domestication of the wild rabbit began around the 11th century in the southern part of Europe and some domestic breeds began to appear from the 15th to 16th century [28]. Then, domestic rabbits, which were developed to various breeds adapted for use as pets and the production of fur and meat, spread worldwide through Europe. The use of rabbits as a laboratory animal started from the mid-19th century and they have been used for studies in physiology, microbiology (infectious diseases), and immunology (vaccines) [29].

At present, laboratory rabbits are generally thought to have unique features as follows: a medium size (i.e., not small like a mouse or rat and not as large as a dog or monkey), ease of handling and breeding in the laboratory because of their tame nature and high reproductivity, blood sampling and intravenous injection are easy because of their large ear, and they are post-coital ovulation animals with a double uterus and large cecum. For safety and development studies of new drugs, rabbits have been used for pharmacokinetics, reproductive and developmental toxicity, local irritation tests, and pyrogenic tests. For research use, the rabbit has been used in the fields of developmental biology and reproductive physiology. As a result of that the rabbit is a post-coital ovulation animal, it is easy to estimate the time of ovulation and developmental stages of embryos. The rabbit was the first mammal to successfully undergo in vitro fertilization (IVF) and intracytoplasmic sperm injection (ICSI) to obtain pups [30,31]. Additionally, the rabbit has been used as an ideal model of atherosclerosis because of its body size, easy manipulation, and extraordinary response to dietary cholesterol [32]. 


\section{History of the Methods to Produce Transgenic Rabbits}

\subsection{Traditional Pronuclear Microinjection to Generate Transgenic Rabbits}

After the first production of transgenic rabbits using the pronuclear microinjection method by Hammer et al. [6], almost all transgenic rabbits have been produced by this method. Pronuclear microinjection remains as the major method to produce transgenic animals, but transgenic efficiency is generally low in rabbits $[9,11]$. The production efficiency of a transgenic rabbit is thought to be influenced by several factors such as DNA quality (concentration, purity, and size), the skill of microinjection technician, and the colony of rabbit breed. In our laboratory, we have produced more than eight types of transgenic rabbits to study human diseases. The mean efficiency of the transgenic rate was lower than $5 \%$ of total born rabbits and $0.5 \%$ of the total injected and transplanted embryos [11]. Moreover, using the pronuclear microinjection method, we cannot control the gene copy number or the insertion site in a chromosome. Therefore, we sometimes encountered the "position effect". In this case, we may not be successful in demonstrating protein expression, even though we have successfully generated transgenic founders. The expression levels of the transgene may depend on both the insertion site and copy number. Therefore, several alternative transgenic methods to pronuclear microinjection for improvement of the transgenic efficiency and stability have been explored in rabbits. For example, the sperm vector [12,33,34], ICSI-mediated transgenesis [35,36], transgenesis by somatic cell nuclear transfer (SCNT) [37] or chimeric SCNT [13,38], lentiviral vectors [14], transposon-mediated transgenesis [15,39], and novel genome editing technology [16,40,41] have been examined to produce transgenic rabbits. The characteristics of these major historical techniques are summarized in Table 1. Currently, the most expected alternative candidate that is better than traditional pronuclear microinjection should be novel genome editing technology. In particular, the CRISPR/Cas9 mediated genome editing technique is a powerful tool to generate genetically modified animals. Recently, the detail of genome engineering technologies in rabbits was well reviewed by Song et al. [42].

Table 1. History of transgene methods for the production of transgenic rabbits.

\begin{tabular}{|c|c|c|}
\hline Reported Year/Technique & Remarks & Ref. \\
\hline $\begin{array}{l}1985 \\
\text { Pronuclear microinjection }\end{array}$ & $\begin{array}{l}\text { The gene copy number and insertion site in a chromosome are } \\
\text { uncontrollable (the position effect will sometimes occur). } \\
\text { Low efficiency (less than } 5 \% \text { of total born rabbits and } 0.5 \% \text { of total } \\
\text { injected embryos) [11] }\end{array}$ & [6] \\
\hline $\begin{array}{l}2006 \\
\text { Sperm vector (SMGT, TMGT and } \\
\text { ICSI-mediated) }\end{array}$ & $\begin{array}{l}\text { High efficiency ( } 48.4-85.7 \% \text { of total born rabbits) } \\
\text { Simple and high performance but unstable (authors could not obtain } \\
\text { transgenic offspring) }\end{array}$ & {$[12,33-36]$} \\
\hline $\begin{array}{l}2009 \\
\text { SCNT (somatic cell nuclear transfer) }\end{array}$ & $\begin{array}{l}\text { Very difficult technique (efficiency was } 1.2-3.5 \% \text { of reconstituted and } \\
\text { transferred embryos) }\end{array}$ & {$[13,37,38]$} \\
\hline $\begin{array}{l}2010 \\
\text { Lentiviral vector (simian } \\
\text { immunodeficiency virus) }\end{array}$ & $\begin{array}{l}\text { The founder rabbit will be a mosaic. Transgenic offspring can be } \\
\text { obtained if transgenes integrate into sperm or oocytes, but at a low } \\
\text { transmission rate. } \\
\text { High efficiency in F0 ( } 32 \% \text { of total born rabbits and } 9.4 \% \text { of total } \\
\text { injected embryos) }\end{array}$ & {$[14]$} \\
\hline $\begin{array}{l}2013 \\
\text { Transposon mediated gene transfer } \\
\text { (Sleeping beauty) }\end{array}$ & $\begin{array}{l}\text { A single copy of the transgene was integrated and maintained for } \\
\text { multiple generations }(\geq 4) \text { without any sign of epigenetic silencing of } \\
\text { transgene expression. } \\
\text { High efficiency ( } 15.2 \% \text { of total born rabbits and } 1.5 \% \text { of total } \\
\text { injected embryos) }\end{array}$ & {$[15,39]$} \\
\hline $\begin{array}{l}2016 \\
\text { Novel genome editing technology } \\
\text { (CRISPR/Cas9 mediated gene transfer) }\end{array}$ & $\begin{array}{l}\text { Knock-in rabbits } \\
\text { The knock-in efficiency rate decreases with kb-sized (large) donor DNA. } \\
\text { HDR enhancer RS- } 1 \text { increases knock-in efficiency. } \\
\text { High efficiency ( } 26.3-35.0 \% \text { of total born rabbits and } 6.8-7.0 \% \text { of total } \\
\text { injected embryos) } \\
\text { Off-target effects remain. }\end{array}$ & {$[16,40,41]$} \\
\hline
\end{tabular}




\subsection{Novel Genome Editing Technologies to Generate Knock-In (Transgenic) Rabbits}

In the past decade, the emergence of novel genome editing technologies, such as ZNF, TALEN, and CRISPR/Cas9, has dramatically changed the rate of progress in current biomedical science. In 2012, Jinek et al. [43] found that Cas9, which is a component of the CRISPR/Cas system, is a DNA endonuclease dependent on RNA, which generates site-specific double-stranded DNA breaks (DSBs). In 2013, several groups succeeded in genome engineering of mammalian cultured cells using the CRISPR/Cas9 system [44,45]. This technique allows deletion and displacement of a specific DNA sequence with high efficiency and ease. The genome editing by the CRISPR/Cas9 system is much simpler and easier than ZNF and TALEN, and shows high efficiency. It enables the generation of knockout animals using fertilized eggs of any species without established ES cells.

CRISPR was discovered as an acquired immunity system (i.e., an exclusion system for foreign DNA) in Eubacterium and Archaebacterium. The Cas9 protein forms a complex with gRNA that has a homology sequence of target DNA and induces a site-specific DSB. In the CRISPR/Cas9 system, it is only 20 bases in the gRNA of approximately 100 bases, which prescribe the target sequence of the DSB. Therefore, only 20 bases need to be changed for each target and all other base sequences and Cas 9 are common. Additionally, the gRNA can be easily obtained from a manufacturing company. As a result of these reasons, the CRISPR/Cas9 system underwent rapid widespread use, even by inexperienced researchers, in molecular biology experiments as a genome editing tool.

The genome editing by CRISPR/Cas9 has potential benefits to not only generate knockout animals, but also produce knock-in animals by gene integration into specific DSB sites of host DNA when the donor ssDNA (subject genetic sequence including the homology arm of both sides) is added to gRNA and Cas9 mRNA or Cas9 protein at microinjection into embryos. The integration of donor DNA was limited to the small single-stranded oligodeoxynucleotide (ssODN) and the insertion efficiency was low at first, but the integration rate of kb-based ssDNA has increased owing to the improvement of genome editing technology. Recently, Song et al. [16] reported that RS-1, a homologous recombination (HDR) enhancer, increases the efficiency of producing knock-in rabbits through the genome editing technique. They knocked in enhanced green fluorescent protein (EGFP) and tdTomato genes into the Rosa26 locus of the rabbit by this method and reported knock-in efficiencies of $26.3-35.0 \%$ of total born rabbits and $6.8-7.0 \%$ of the total injected embryos [16,29]. Using this method, the knock-in efficiency should be more than 10-fold that of traditional pronuclear microinjection.

In 2014, Kaneko et al. [46] reported successful introduction of endonuclease mRNAs into zygotes to induce editing at targeted loci and efficiently produced knockout rats by the electroporation method with a high survival rate. It is noteworthy that electroporation of ZFNs resulted in an embryonic survival rate of $91 \%$ and a genome editing rate of $73 \%$. This method has some advantages compared with the traditional microinjection technique. Using this method, specialized skills for microinjection are not needed and a large number of zygotes can be manipulated at one time. The electroporation technique may accelerate the production of genetically modified animals because of its simplicity and ease. New technologies and techniques applicable to the production of genetically modified animals are developing and improving daily.

\section{Transgenic Rabbits for Human Disease Models}

Transgenic rabbits as human disease models [47-115] are listed in Table 2. 
Table 2. Transgenic rabbits for human disease models.

\begin{tabular}{|c|c|c|}
\hline Possible Disease Models/Transgene & Remarks & Ref. \\
\hline \multicolumn{3}{|l|}{ Lipid metabolism and atherosclerosis } \\
\hline Human apo(a) & & [47] \\
\hline Human apo(a) and apoB & & [48] \\
\hline Human apo A-I & & {$[49,50]$} \\
\hline Human apoA-I/C-III/A-IV gene cluster & & [51] \\
\hline Human apoA-II & & [52] \\
\hline Human apoB & & [53] \\
\hline Human apoB-100 & & [54] \\
\hline Human APOBEC1 & & [55] \\
\hline Rabbit apobec-shRNA & RNA-i knockdown of rabbit APOBEC1 & [56] \\
\hline Human apoC-III & Knockout was also produced [27] & [57] \\
\hline Human apoE2 & \multirow{2}{*}{ Knockout was also produced $[25,26]$} & {$[58]$} \\
\hline Human apoE3 & & {$[59,60]$} \\
\hline Human CETP & \multirow[t]{5}{*}{ Knockout was also produced [22] } & [61] \\
\hline Human CRP & & {$[62]$} \\
\hline Human EL & & {$[63,64]$} \\
\hline Human HL & & {$[65,66]$} \\
\hline Human LCAT & & {$[67,68]$} \\
\hline 15-Lipoxygenase type 1 & Osteoporosis and periodontal disease $[69,70]$ & {$[71]$} \\
\hline Human LPL & \multirow[t]{3}{*}{ Obesity [72] } & {$[73,74]$} \\
\hline Rabbit MMP-1 & & [75] \\
\hline Human MMP-9 & & [76] \\
\hline Human MMP-12 & \multirow[t]{3}{*}{ Inflammation [77] } & [78] \\
\hline Human PLTP & & [79] \\
\hline Human Urotensin II & & [80] \\
\hline \multicolumn{3}{|l|}{ Cardiac failure } \\
\hline \multicolumn{3}{|l|}{ Hypertrophic cardiomyopathy/cardiac protein } \\
\hline Rabbit $\alpha$-MyHC & & [81-84] \\
\hline Rabbit cThI-G146 mutation & & [85] \\
\hline Rabbit Cardiac Gs $\alpha$ & & {$[86,87]$} \\
\hline Rabbit ELC1v-M149V mutation & & [88] \\
\hline Rabbit Phospholamban & & [89] \\
\hline Human $\beta$-MyHC-R403Q mutation & & {$[90]$} \\
\hline Rabbit $\beta$-MyHC-R403 mutation & & {$[91,92]$} \\
\hline RyR2 R4497C & & [93] \\
\hline \multicolumn{3}{|l|}{ Proarrhythmia } \\
\hline Human KvLQT1-Y315S mutation (LQT1) & \multirow[t]{3}{*}{ Long QT syndrome } & {$[94,95]$} \\
\hline Human HERG-G628S mutation (LQT2) & & {$[94,95]$} \\
\hline Human KCNE1-G52R mutation (LQT5) & & {$[96,97]$} \\
\hline \multicolumn{3}{|l|}{ Immunology } \\
\hline Human HLA-A2.1 & Immunity to viral infection & [98] \\
\hline Rabbit FcRn & Humoral immune response & [99] \\
\hline Rabbit IgH & B cell-deficient (B cell development) & [100] \\
\hline Human CD4 & AIDS & [101-103] \\
\hline Human CD55 and CD59 & Xenotransplantation & [104] \\
\hline \multicolumn{3}{|l|}{ Tumor (oncogenesis) } \\
\hline Rabbit EJ-ras DNA & Papilloma, keratoacanthomas and squamous cell carcinoma & {$[105,106]$} \\
\hline Rabbit c-myc oncogene & Lymphocytic leukemia & [107] \\
\hline Rabbit E-K-myc oncogene & Lymphoid tumor & [108] \\
\hline \multicolumn{3}{|l|}{ Other models } \\
\hline Bovine GH & Acromegaly and diabetes mellitus & [109] \\
\hline EGFP & Marker for tissue engineering and regenerative medicine & [110] \\
\hline Oct4 promoter-EGFP & Marker to investigate rabbit embryo development & [111] \\
\hline Ovine PrP & Rabbits are susceptible to a various prion isolates [116]. & [112] \\
\hline Rabbit Rhodopsin-P347L mutation & Retinitis pigmentosa & [113] \\
\hline Human VEGF & $\begin{array}{l}\text { Hepatic hemangioma (Kasabach-Merritt syndrome), } \\
\text { and renal dysfunction }\end{array}$ & {$[114,115]$} \\
\hline
\end{tabular}

APOBEC1, APOB mRNA editing protein; CETP, cholesteryl ester transfer protein; CRP, C-reactive protein; EL, endothelial Lipase; HL, hepatic lipase; LCAT, lecithin: cholesterol acyltransferase; LPL, LPL, lipoprotein lipase; MMP, matrix metalloproteinase; PLTP, plasma phospholipid transfer protein; MyHC, myosin heavy chain; cTnI, cardiac troponin I; ELC1v, essential myosin light chain 1; RyR2, cardiac ryanodine receptor. HLA, human leukocyte antigens; FcRn, neonatal Fc receptor; GH, growth hormone; EGFP, enhanced green fluorescent protein; PrP, prion related protein; VEGF, vascular endothelial growth factor. 
The most-used research areas of transgenic rabbits as human disease models are lipid metabolism and atherosclerosis. In fact, thus far, more than 20 genes related to lipid metabolism and atherosclerosis have been introduced into transgenic rabbits (Table 2). Transgenic rabbits have also been used as disease models for cardiac failure (hypertrophic cardiomyopathy and proarrhythmic), immunology (immunity to viral infection, humoral immune response, and transplantation), and oncogenesis because of the physiological features of laboratory rabbits. The most important physiological feature of rabbits is that they have a similar lipid metabolic system to humans, whereas the mouse is quite different (Table 3) [3-5]. In mice, the major lipoproteins in plasma are high density lipoprotein (HDL) owing to the lack of cholesterol ester transfer protein. Furthermore, because rabbits do not have hepatic apolipoprotein-(apo)B mRNA editing activity, rabbit apoB-48 is only present in intestinally derived chylomicrons, which is similar to humans, unlike mice and rats in which apoB-48 is contained in both chylomicrons and hepatically derived very low density lipoprotein and low density lipoprotein (LDL). There are other differences between humans, rabbits, and mice, such as the localized patterns of hepatic lipase (HL), an important enzyme in the metabolism of chylomicron remnants, and HDL. In humans and rabbits, HL is bound to a proteoglycan on the surface of hepatic or endothelial cells, whereas $70 \%$ or more HL in mice is in its free state and is released into blood without binding to the cell surface. Therefore, mice are resistant to cholesterol-rich diets and have difficulty in developing hypercholesterolemia and atherosclerosis. The characteristic details of transgenic rabbit models for lipid metabolism and atherosclerosis have been described in several reviews $[3,7,8]$. Interestingly, among these reviews, Fan and Watanabe [3] mentioned that phenotypes are different between mice and rabbits even when the same genes are introduced. For example, the expression of either human HL or lecithin cholesterol acyltransferase (LCAT) induces enhanced lesion formation in transgenic mice but protects against atherosclerosis in rabbits. Overexpression of apoE in mice inhibits atherosclerosis but leads to increased plasma LDL and spontaneous atherosclerosis in transgenic rabbits. High expression of human lipoprotein lipase results in myopathy in transgenic mice but not in transgenic rabbits. These observations strongly suggest that the difference in the physiological background among species affects the result of studies using human disease animal models. To extrapolate results from animal experimentation to humans, we must focus on the appropriate species depending on the purpose of the study. In addition to lipid metabolism, the myocardium composition of rabbits is also similar to that of humans (Table 3). In the human heart, $\beta$-myosin heavy chain ( $\beta$-MyHC) comprises $90 \%$ of total myofibrillar myosin. In the rabbit heart, similarly to humans, $80 \%$ consists of $\beta-\mathrm{MyCH}$ in contrast to the mouse heart predominated by the other myosin isoform, $\alpha$-myosin heavy chain $(\alpha-\mathrm{MyCH})$, at $95 \%[9,117]$. These physiological features of the rabbit can be useful for human disease models of cardiac failure, such as hypertrophic cardiopathy and proarrhythmia. To date, novel transgenic rabbits have been continuously produced and used as human disease models in lipid metabolism and atherosclerosis. Unique transgenic rabbit models have also been reported in other research areas such as Rhodopsin P347L transgenic rabbits for retinitis pigmentosa [113] and Ovine PrP transgenic rabbit for prion disease $[112,116]$ (Table 2). In the future, it is expected that the use of transgenic rabbits will expand to various research fields except for lipid metabolism, atherosclerosis, and cardiac failure. 
Table 3. Comparison of lipid metabolism and cardiac characteristics between mice, rabbits, and humans.

\begin{tabular}{lccc}
\hline & Mouse & Rabbit & Human \\
\hline Lipoprotein profile & HDL-rich & LDL-rich & LDL-rich \\
CETP & None & Abundant & Abundant \\
Hepatic apoB mRNA editing & Yes & No & No \\
apoB48 & VLDLs/LDLs and & Chylomicrons & Chylomicrons \\
& chylomicrons & & \\
Hepatic lipase & High, 70\% in & Low, liver-bound & Low, liver-bound \\
Hepatic LDL receptor & circulation & Down-regulated & Down-regulated \\
apoA-II & Usually high & Absent & Dimmer \\
Dietary cholesterol & Monomer & Sensitive & Sensitive \\
Atherosclerosis & Resistant & Susceptible & - \\
Myosin type of myocardium & Resistant & $\beta$-MyHC & $\beta$-MyHC \\
Ion channel of myocardium & $\alpha-M y H C$ & $\mathrm{I}_{\mathrm{kr}}$ and $\mathrm{I}_{\mathrm{ks}}$ & $\mathrm{I}_{\mathrm{kr}}$ and $\mathrm{I}_{\mathrm{ks}}$ \\
ECG pattern & $\mathrm{I}_{\text {to }}$ and $\mathrm{I}_{\mathrm{kslow}}$ & T-wave & T-wave \\
& J-wave & $(12$ lead) & $(12$ lead) \\
\hline
\end{tabular}

HDL, high density lipoprotein; LDL, low density lipoprotein; CETP, cholesteryl ester transfer protein; VLDL, very low density lipoprotein; MyHC, myosin heavy chain; ECG, electrocardiogram. Modified from Fan et al. [3,5].

\section{Transgenic Rabbit as a Bioreactor}

Lastly, we will briefly discuss transgenic rabbits as bioreactors. In a bioreactor, recombinant proteins are expressed in mammary gland epithelial cells and produced in the milk of transgenic animals. By purifying the recombinant proteins from the milk, useful substances can be obtained at lower costs than conventional production methods such as cell culture systems $[10,118]$. For this purpose, large animals are believed to be suitable as bioreactors because they produce a large amount of milk. In contrast, rabbits require a simple means of farming compared with larger livestock. Breeding rabbits in a laboratory is also possible and they mature early (5-6 months of age) [119]. Their reproductive capacity is high and they deliver six to eight pups per birth. Additionally, rabbits do not have seasonal reproductive cycles and the amount of milk per lactation period is 1-1.5 L [119]. Therefore, rabbits are quite suitable for small scale production and allow rapid development of recombinant proteins. Many researchers have reported the production of valuable physiologically active substances using transgenic rabbits $[3,7,8]$.

The first therapeutic protein produced by a bioreactor for a human disease was antithrombin III $\left(\right.$ Atrin ${ }^{\circledR}$ ) from goat milk, which was approved in 2006 in the EU and 2010 the USA. Therapeutic protein from rabbit milk have also been approved, such as C1-esterase inhibitor (Ruconest ${ }^{\circledR}$ ) for hereditary angioedema in 2010 (EU) and 2014 (USA), and Factor VIIa (Sevenfact ${ }^{\circledR}$ ) for hemophilia A or B and inhibitors in 2020 (USA).

\section{Conclusions and Future Perspectives}

The development of gene engineering technology has enabled the generation of transgenic rabbits that have contributed to the progress of biomedical science as an animal model in several research fields where the mouse is unsuitable as a research model. To extrapolate results from animal experimentation to humans, we must focus on the appropriate species depending on the purpose of the study. Rabbits have some unique features such as a lipid metabolism system very close to humans and a medium body size (not too small like mouse and rat, and not too large like dog and monkey) that is easily handled and applied to experimental manipulation. Therefore, many transgenic rabbits have been produced as animal models for lipid metabolism and atherosclerosis, cardiac failure, immunology, and oncogenesis. For a long time, the transgenic efficiency of rabbits was low and production of knockout rabbits was difficult because of the lack of rabbit ES cells. However, these problems were solved by the emergence of novel genome editing technology in this decade. We can now easily produce both transgenic and knockout rabbit models to analyze gain or loss of functions, or both. In the future, it is 
expected that the use of genetically modified rabbits will expand to various research fields including lipid metabolism, atherosclerosis, and cardiac failure.

Genome editing technology may replace the traditional pronuclear microinjection method to produce transgenic rabbits because of the high efficiency of the knock-in (transgenic) rate. In knock-in rabbits produced by genome editing technology, one transgene is usually integrated at the DSB site in contrast to the pronuclear microinjection method that ranges from two to 100 copies or more. The transgene copy number should be considered when analyzing a target gene if it requires a high expression transgenic model. However, expression of a transgene may be out of proportion to the integrated transgene copy number. Moreover, extremely high expression beyond the physiological tolerance level may cause undesirable effects on animals and will not reflect the condition of the human disease. Additionally, complicated gene manipulation, such as conditional gene knockout in an organ-specific and time-controlled manner using the Cre/LoxP system, may be difficult in rabbits. As a result of that a long time is needed for a change in generation owing to the half year required for sexual maturation of rabbits, and there are no available inbred strains (a closed colony is common), brother-sister mating has difficulty to produce the homozygote genotype needed for the experiment in a short period. Moreover, a relatively large breeding colony is needed to avoid the inbreeding depression caused by brother-sister mating. Thus far, there are no reports about a conditional gene targeting model in the rabbit and it will be necessary to perform further studies.

Lastly, the preservation of useful strains of genetically modified rabbits will become an important task after their production. Currently, the cryopreservation of sperm and embryos has become a common a method to preserve laboratory animal strains, especially mice and rats. By cryopreservation of sperm and embryos, we will be able to reduce costs and space in animal breeding facilities and avoid accidents that might occur when transporting living animals. To maintain rabbit strains, the cost and occupying space in an animal facility will be problems with the increasing number of genetically modified rabbit strains for preservation. The advantages of cryopreservation of sperm and embryos are very useful for rabbits. For rabbits, several studies have reported various procedures for cryopreservation of sperm [120-122] and embryos [123-125], but a standard has not been established yet. In the future, it is expected that the development and establishment of cryopreservation methods for the rabbit and a rabbit bioresource center as a sperm and embryo bank of useful rabbit strains to provide them to researchers worldwide will increase the use of valuable genetically modified rabbits.

Author Contributions: All the authors contributed to writing the original draft and revising the final version. All authors have read and agreed to the published version of the manuscript.

Funding: This work was supported in part by JSPS KAKENHI Grant Number 13877027, 15500299, 19500362, 22500386, 25430091 and 17K07138.

Acknowledgments: We would like to thank Eriguchi, R., Tsuneyoshi, R., Shimazaki, Y., Nakanishi, Y., Kanna, T., Higuchi, A., Watanabe, N., Mukohira, R., Yoshioka, S., Matsuo, K., Tanaka, M., Yamaguchi, S. and Maeda, T. in our laboratory, Saga University for their technical supports. We are also grateful to Niimi, M. and Koike, T., Yamanashi University, Liu, E., Xi'an Jiaotong University, and Watanabe, T., emeritus professor of Saga University for their collaboration and advices to this work.

Conflicts of Interest: The authors declare no conflict of interest.

\section{References}

1. Gordon, J.W.; Scangos, G.A.; Plotkin, D.J.; Barbosa, J.A.; Ruddle, F.H. Genetic transformation of mouse embryos by microinjection of purified DNA. Proc. Natl. Acad. Sci. USA 1980, 77, 7380-7384. [CrossRef]

2. Capecchi, M.R. The new mouse genetics: Altering the genome by gene targeting. Trends Genet. 1989, 5, 70-76. [CrossRef]

3. Fan, J.; Watanabe, T. Transgenic rabbits as therapeutic protein bioreactors and human disease models. Pharmacol. Ther. 2003, 99, 261-282. [CrossRef]

4. Fan, J.; Kitajima, S.; Watanabe, T.; Xu, J.; Zhang, J.; Liu, E.; Chen, Y.E. Rabbit models for the study of human atherosclerosis: From pathophysiological mechanisms to translational medicine. Pharmacol. Ther. 2015, 146, 104-119. [CrossRef] [PubMed] 
5. Fan, J.; Chen, Y.; Yan, H.; Niimi, M.; Wang, Y.; Liang, J. Principles and Applications of Rabbit Models for Atherosclerosis Research. J. Atheroscler. Thromb. 2018, 25, 213-220. [CrossRef] [PubMed]

6. Hammer, R.E.; Pursel, V.G.; Rexroad, C.E., Jr.; Wall, R.J.; Bolt, D.J.; Ebert, K.M.; Palmiter, R.D.; Brinster, R.L. Production of transgenic rabbits, sheep and pigs by microinjection. Nature 1985, 315, 680-683. [CrossRef] [PubMed]

7. Bosze, Z.; Hiripi, L.; Carnwath, J.W.; Niemann, H. The transgenic rabbit as model for human diseases and as a source of biologically active recombinant proteins. Transgenic Res. 2003, 12, 541-553. [CrossRef] [PubMed]

8. Kitajima, S.; Morimoto, M.; Watanabe, T.; Fan, J. Transgenic Rabbits: Production and Application for Human Disease Models. Recent Res. Dev. Biophys. Biochem. 2003, 3, 179-194.

9. Bősze, Z.; Major, P.; Baczkó, I.; Odening, K.E.; Bodrogi, L.; Hiripi, L.; Varró, A. The potential impact of new generation transgenic methods on creating rabbit models of cardiac diseases. Prog. Biophys. Mol. Biol. 2016, 121, 123-130. [CrossRef]

10. Bertolini, L.R.; Meade, H.; Lazzarotto, C.R.; Martins, L.T.; Tavares, K.C.; Bertolini, M.; Murray, J.D. The transgenic animal platform for biopharmaceutical production. Transgenic Res. 2016, 25, 329-343. [CrossRef]

11. Kitajima, S.; Liu, E.; Fan, J. Rabbit transgenesis. In Rabbit Biotechnology; Houdebine, L., Fan, J., Eds.; Springer: Heidelberg, Germany, 2009; pp. 37-48.

12. Shen, W.; Li, L.; Pan, Q.; Min, L.; Dong, H.; Deng, J. Efficient and simple production of transgenic mice and rabbits using the new DMSO-sperm mediated exogenous DNA transfer method. Mol. Reprod. Dev. 2006, 73, 589-594. [CrossRef]

13. Skrzyszowska, M.; Smorag, Z.; Slomski, R.; Katska-Ksiazkiewicz, L.; Kalak, R.; Michalak, E.; Wielgus, K.; Lehmann, J.; Lipinski, D.; Szalata, M.; et al. Generation of transgenic rabbits by the novel technique of chimeric somatic cell cloning. Biol. Reprod. 2006, 74, 1114-1120. [CrossRef] [PubMed]

14. Hiripi, L.; Negre, D.; Cosset, F.L.; Kvell, K.; Czompoly, T.; Baranyi, M.; Gocza, E.; Hoffmann, O.; Bender, B.; Bosze, Z. Transgenic rabbit production with simian immunodeficiency virus-derived lentiviral vector. Transgenic Res. 2010, 19, 799-808. [CrossRef] [PubMed]

15. Katter, K.; Geurts, A.M.; Hoffmann, O.; Mates, L.; Landa, V.; Hiripi, L.; Moreno, C.; Lazar, J.; Bashir, S.; Zidek, V.; et al. Transposon-mediated transgenesis, transgenic rescue, and tissue-specific gene expression in rodents and rabbits. FASEB J. 2013, 27, 930-941. [CrossRef] [PubMed]

16. Song, J.; Yang, D.; Xu, J.; Zhu, T.; Chen, Y.E.; Zhang, J. RS-1 enhances CRISPR/Cas9- and TALEN-mediated knock-in efficiency. Nat. Commun. 2016, 7, 10548. [CrossRef]

17. Schoonjans, L.; Albright, G.M.; Li, J.L.; Collen, D.; Moreadith, R.W. Pluripotential rabbit embryonic stem (ES) cells are capable of forming overt coat color chimeras following injection into blastocysts. Mol. Reprod. Dev. 1996, 45, 439-443. [CrossRef]

18. Honsho, K.; Hirose, M.; Hatori, M.; Yasmin, L.; Izu, H.; Matoba, S.; Togayachi, S.; Miyoshi, H.; Sankai, T.; Ogura, A.; et al. Naive-like conversion enhances the difference in innate in vitro differentiation capacity between rabbit ES cells and iPS cells. J. Reprod. Dev. 2015, 61, 13-19. [CrossRef]

19. Flisikowska, T.; Thorey, I.S.; Offner, S.; Ros, F.; Lifke, V.; Zeitler, B.; Rottmann, O.; Vincent, A.; Zhang, L.; Jenkins, S.; et al. Efficient immunoglobulin gene disruption and targeted replacement in rabbit using zinc finger nucleases. PLoS ONE 2011, 6, e21045. [CrossRef]

20. Song, J.; Zhong, J.; Guo, X.; Chen, Y.; Zou, Q.; Huang, J.; Li, X.; Zhang, Q.; Jiang, Z.; Tang, C.; et al. Generation of RAG 1- and 2-deficient rabbits by embryo microinjection of TALENs. Cell Res. 2013, 23, 1059-1062. [CrossRef]

21. Yan, Q.; Zhang, Q.; Yang, H.; Zou, Q.; Tang, C.; Fan, N.; Lai, L. Generation of multi-gene knockout rabbits using the Cas9/gRNA system. Cell Regen. 2014, 3, 12. [CrossRef]

22. Zhang, J.; Niimi, M.; Yang, D.; Liang, J.; Xu, J.; Kimura, T.; Mathew, A.V.; Guo, Y.; Fan, Y.; Zhu, T.; et al. Deficiency of Cholesteryl Ester Transfer Protein Protects Against Atherosclerosis in Rabbits. Arterioscler. Thromb. Vasc. Biol. 2017, 37, 1068-1075. [CrossRef] [PubMed]

23. Song, Y.; Xu, Y.; Liang, M.; Zhang, Y.; Chen, M.; Deng, J.; Li, Z. CRISPR/Cas9-mediated mosaic mutation of SRY gene induces hermaphroditism in rabbits. Biosci. Rep. 2018, 38, BSR20171490. [CrossRef]

24. Sui, T.; Liu, D.; Liu, T.; Deng, J.; Chen, M.; Xu, Y.; Song, Y.; Ouyang, H.; Lai, L.; Li, Z. LMNA-mutated Rabbits: A Model of Premature Aging Syndrome with Muscular Dystrophy and Dilated Cardiomyopathy. Aging Dis. 2019, 10, 102-115. [CrossRef] 
25. Niimi, M.; Yang, D.; Kitajima, S.; Ning, B.; Wang, C.; Li, S.; Liu, E.; Zhang, J.; Eugene Chen, Y.; Fan, J. ApoE knockout rabbits: A novel model for the study of human hyperlipidemia. Atherosclerosis 2016, 245, 187-193. [CrossRef] [PubMed]

26. Yang, D.; Xu, J.; Zhu, T.; Fan, J.; Lai, L.; Zhang, J.; Chen, Y.E. Effective gene targeting in rabbits using RNA-guided Cas9 nucleases. J. Mol. Cell Biol. 2014, 6, 97-99. [CrossRef]

27. Yang, D.; Zhang, J.; Xu, J.; Zhu, T.; Fan, Y.; Fan, J.; Chen, Y.E. Production of apolipoprotein C-III knockout rabbits using zinc finger nucleases. J. Vis. Exp. 2013, 81, e50957. [CrossRef] [PubMed]

28. Dice, L. The colorado pika in captivity. J. Mammals 1927, 8, 3. [CrossRef]

29. Esteves, P.J.; Abrantes, J.; Baldauf, H.M.; BenMohamed, L.; Chen, Y.; Christensen, N.; Gonzalez-Gallego, J.; Giacani, L.; Hu, J.; Kaplan, G.; et al. The wide utility of rabbits as models of human diseases. Exp. Mol. Med. 2018, 50, 1-10. [CrossRef]

30. Ogonuki, N.; Inoue, K.; Miki, H.; Mochida, K.; Hatori, M.; Okada, H.; Takeiri, S.; Shimozawa, N.; Nagashima, H.; Sankai, T.; et al. Differential development of rabbit embryos following microinsemination with sperm and spermatids. J. Mol. Reprod. Dev. 2005, 72, 411-417. [CrossRef]

31. Thibault, C.; Dauzier, L.; Wintenberger, S. Cytological study of fecundation in vitro of rabbit ovum. C. $R$. Seances Soc. Biol. Fil. 1954, 148, 789-790.

32. Finking, G.; Hanke, H. Nikolaj Nikolajewitsch Anitschkow (1885-1964) established the cholesterol-fed rabbit as a model for atherosclerosis research. Atherosclerosis 1997, 135, 1-7. [CrossRef]

33. Li, L.; Shen, W.; Min, L.; Dong, H.; Sun, Y.; Pan, Q. Human lactoferrin transgenic rabbits produced efficiently using dimethylsulfoxide-sperm-mediated gene transfer. Reprod. Fertil. Dev. 2006, 18, 689-695. [CrossRef]

34. Wang, H.J.; Lin, A.X.; Chen, Y.F. Association of rabbit sperm cells with exogenous DNA. Anim. Biotechnol. 2003, 14, 155-165. [CrossRef] [PubMed]

35. Li, Q.; Hou, J.; Wang, S.; Chen, Y.; An, X.R. Production of transgenic rabbit embryos through intracytoplasmic sperm injection. Zygote 2010, 18, 301-307. [CrossRef]

36. Zhang, S.; Lu, F.; Liu, Q.; Liu, Y.; Guan, X.; Wie, Y.; Tan, S.; Shi, D. Efficient generation of sFat-1 transgenic rabbits rich in n-3 polyunsaturated fatty acids by intracytoplasmic sperm injection. Reprod. Fertil. Dev. 2016, 28, 310-318. [CrossRef] [PubMed]

37. Li, S.; Guo, Y.; Shi, J.; Yin, C.; Xing, F.; Xu, L.; Zhang, C.; Liu, T.; Li, Y.; Li, H.; et al. Transgene expression of enhanced green fluorescent protein in cloned rabbits generated from in vitro-transfected adult fibroblasts. Transgenic Res. 2009, 18, 227-235. [CrossRef] [PubMed]

38. Matsuda, J.; Takahashi, S.; Ohkoshi, K.; Kaminaka, K.; Kaminaka, S.; Nozaki, C.; Maeda, H.; Tokunaga, T. Production of transgenic chimera rabbit fetuses using somatic cell nuclear transfer. Cloning Stem Cells 2002, 4, 9-19. [CrossRef]

39. Ivics, Z.; Hiripi, L.; Hoffmann, O.I.; Mates, L.; Yau, T.Y.; Bashir, S.; Zidek, V.; Landa, V.; Geurts, A.; Pravenec, M.; et al. Germline transgenesis in rabbits by pronuclear microinjection of Sleeping Beauty transposons. Nat. Protoc. 2014, 9, 794-809. [CrossRef]

40. Li, H.; Li, Z.; Xiao, N.; Su, X.; Zhao, S.; Zhang, Y.; Cui, K.; Liu, Q.; Shi, D. Site-specific integration of rotavirus VP6 gene in rabbit beta-casein locus by CRISPR/Cas9 system. In Vitro Cell Dev. Biol. Anim. 2019, 55, 586-597. [CrossRef]

41. Yang, D.; Song, J.; Zhang, J.; Xu, J.; Zhu, T.; Wang, Z.; Lai, L.; Chen, Y.E. Identification and characterization of rabbit ROSA26 for gene knock-in and stable reporter gene expression. Sci. Rep. 2016, 6, 25161. [CrossRef]

42. Song, J.; Zhang, J.; Xu, J.; Garcia-Barrio, M.; Chen, Y.E.; Yang, D. Genome engineering technologies in rabbits. J. Biomed. Res. 2020, 1-13. [CrossRef] [PubMed]

43. Jinek, M.; Chylinski, K.; Fonfara, I.; Hauer, M.; Doudna, J.A.; Charpentier, E. A programmable dual-RNA-guided DNA endonuclease in adaptive bacterial immunity. Science 2012, 337, 816-821. [CrossRef] [PubMed]

44. Mali, P.; Yang, L.; Esvelt, K.M.; Aach, J.; Guell, M.; DiCarlo, J.E.; Norville, J.E.; Church, G.M. RNA-guided human genome engineering via Cas9. Science 2013, 339, 823-826. [CrossRef] [PubMed]

45. Cong, L.; Ran, F.A.; Cox, D.; Lin, S.; Barretto, R.; Habib, N.; Hsu, P.D.; Wu, X.; Jiang, W.; Marraffini, L.A.; et al. Multiplex genome engineering using CRISPR/Cas systems. Science 2013, 339, 819-823. [CrossRef]

46. Kaneko, T.; Sakuma, T.; Yamamoto, T.; Mashimo, T. Simple knockout by electroporation of engineered endonucleases into intact rat embryos. Sci. Rep. 2014, 4, 6382. [CrossRef] 
47. Fan, J.; Araki, M.; Wu, L.; Challah, M.; Shimoyamada, H.; Lawn, R.M.; Kakuta, H.; Shikama, H.; Watanabe, T. Assembly of lipoprotein(a) in transgenic rabbits expressing human apolipoprotein(a). Biochem. Biophys. Res. Commun. 1999, 255, 639-644. [CrossRef] [PubMed]

48. Rouy, D.; Duverger, N.; Lin, S.D.; Emmanuel, F.; Houdebine, L.M.; Denefle, P.; Viglietta, C.; Gong, E.; Rubin, E.M.; Hughes, S.D. Apolipoprotein(a) yeast artificial chromosome transgenic rabbits. Lipoprotein(a) assembly with human and rabbit apolipoprotein B. J. Biol. Chem. 1998, 273, 1247-1251. [CrossRef] [PubMed]

49. Duverger, N.; Viglietta, C.; Berthou, L.; Emmanuel, F.; Tailleux, A.; Parmentier-Nihoul, L.; Laine, B.; Fievet, C.; Castro, G.; Fruchart, J.C.; et al. Transgenic rabbits expressing human apolipoprotein A-I in the liver. Arterioscler. Thromb. Vasc. Biol. 1996, 16, 1424-1429. [CrossRef]

50. Duverger, N.; Kruth, H.; Emmanuel, F.; Caillaud, J.M.; Viglietta, C.; Castro, G.; Tailleux, A.; Fievet, C.; Fruchart, J.C.; Houdebine, L.M.; et al. Inhibition of atherosclerosis development in cholesterol-fed human apolipoprotein A-I-transgenic rabbits. Circulation 1996, 94, 713-717. [CrossRef]

51. Recalde, D.; Baroukh, N.; Viglietta, C.; Prince, S.; Verona, J.; Vergnes, L.; Pidoux, J.; Nazeem Nanjee, M.; Brites, F.; Ochoa, A.; et al. Human apoA-I/C-III/A-IV gene cluster transgenic rabbits: Effects of a high-cholesterol diet. FEBS Lett. 2004, 572, 294-298. [CrossRef]

52. Koike, T.; Kitajima, S.; Yu, Y.; Li, Y.; Nishijima, K.; Liu, E.; Sun, H.; Waqar, A.B.; Shibata, N.; Inoue, T.; et al. Expression of human apoAII in transgenic rabbits leads to dyslipidemia: A new model for combined hyperlipidemia. Arterioscler. Thromb. Vasc. Biol. 2009, 29, 2047-2053. [CrossRef] [PubMed]

53. Rizzo, M.; Taylor, J.M.; Barbagallo, C.M.; Berneis, K.; Blanche, P.J.; Krauss, R.M. Effects on lipoprotein subclasses of combined expression of human hepatic lipase and human apoB in transgenic rabbits. Arterioscler. Thromb. Vasc. Biol. 2004, 24, 141-146. [CrossRef] [PubMed]

54. Fan, J.; McCormick, S.P.; Krauss, R.M.; Taylor, S.; Quan, R.; Taylor, J.M.; Young, S.G. Overexpression of human apolipoprotein B-100 in transgenic rabbits results in increased levels of LDL and decreased levels of HDL. Arterioscler. Thromb. Vasc. Biol. 1995, 15, 1889-1899. [CrossRef] [PubMed]

55. Hughes, S.D.; Rouy, D.; Navaratnam, N.; Scott, J.; Rubin, E.M. Gene transfer of cytidine deaminase apoBEC-1 lowers lipoprotein (a) in transgenic mice and induces apolipoprotein B editing in rabbits. Hum. Gene. Ther. 1996, 7, 39-49. [CrossRef]

56. Jolivet, G.; Braud, S.; DaSilva, B.; Passet, B.; Harscoet, E.; Viglietta, C.; Gautier, T.; Lagrost, L.; Daniel-Carlier, N.; Houdebine, L.M.; et al. Induction of body weight loss through RNAi-knockdown of APOBEC1 gene expression in transgenic rabbits. PLoS ONE 2014, 9, e106655. [CrossRef]

57. Ding, Y.; Wang, Y.; Zhu, H.; Fan, J.; Yu, L.; Liu, G.; Liu, E. Hypertriglyceridemia and delayed clearance of fat load in transgenic rabbits expressing human apolipoprotein CIII. Transgenic Res. 2011, 20, 867-875. [CrossRef] [PubMed]

58. Huang, Y.; Schwendner, S.W.; Rall, S.C., Jr.; Sanan, D.A.; Mahley, R.W. Apolipoprotein E2 transgenic rabbits. Modulation of teh type III hyperlipoproteinemic phenotype by estrogen and occurrence of spontaneous atherosclerosis. J. Biol. Chem. 1997, 272, 22685-22694. [CrossRef] [PubMed]

59. Huang, Y.; Ji, Z.S.; Brecht, W.J.; Rall, S.C., Jr.; Taylor, J.M.; Mahley, R.W. Overexpression of apolipoprotein E3 in transgenic rabbits causes combined hyperlipidemia by stimulating hepatic VLDL production and impairing VLDL lipolysis. Arterioscler. Thromb. Vasc. Biol. 1999, 19, 2952-2959. [CrossRef]

60. Fan, J.; Ji, Z.S.; Huang, Y.; de Silva, H.; Sanan, D.; Mahley, R.W.; Innerarity, T.L.; Taylor, J.M. Increased expression of apolipoprotein $\mathrm{E}$ in transgenic rabbits results in reduced levels of very low density lipoproteins and an accumulation of low density lipoproteins in plasma. J. Clin. Investig. 1998, 101, 2151-2164. [CrossRef]

61. Gao, S.; Wang, X.; Cheng, D.; Li, J.; Li, L.; Ran, L.; Zhao, S.; Fan, J.; Liu, E. Overexpression of Cholesteryl Ester Transfer Protein Increases Macrophage-Derived Foam Cell Accumulation in Atherosclerotic Lesions of Transgenic Rabbits. Mediat. Inflamm. 2017, 2017, 3824276. [CrossRef]

62. Koike, T.; Kitajima, S.; Yu, Y.; Nishijima, K.; Zhang, J.; Ozaki, Y.; Morimoto, M.; Watanabe, T.; Bhakdi, S.; Asada, Y.; et al. Human C-reactive protein does not promote atherosclerosis in transgenic rabbits. Circulation 2009, 120, 2088-2094. [CrossRef] [PubMed]

63. Wang, C.; Nishijima, K.; Kitajima, S.; Niimi, M.; Yan, H.; Chen, Y.; Ning, B.; Matsuhisa, F.; Liu, E.; Zhang, J.; et al. Increased Hepatic Expression of Endothelial Lipase Inhibits Cholesterol Diet-Induced Hypercholesterolemia and Atherosclerosis in Transgenic Rabbits. Arterioscler. Thromb. Vasc. Biol. 2017, 37, 1282-1289. [CrossRef] [PubMed] 
64. Wang, C.; Niimi, M.; Kitajima, S.; Matsuhisa, F.; Yan, H.; Dong, S.; Liang, J.; Fan, J. Sex hormones affect endothelial lipase-mediated lipid metabolism and atherosclerosis. Lipids Health Dis. 2019, 18, 226. [CrossRef] [PubMed]

65. Fan, J.; Wang, J.; Bensadoun, A.; Lauer, S.J.; Dang, Q.; Mahley, R.W.; Taylor, J.M. Overexpression of hepatic lipase in transgenic rabbits leads to a marked reduction of plasma high density lipoproteins and intermediate density lipoproteins. Proc. Natl. Acad. Sci. USA 1994, 91, 8724-8728. [CrossRef]

66. Barbagallo, C.M.; Fan, J.; Blanche, P.J.; Rizzo, M.; Taylor, J.M.; Krauss, R.M. Overexpression of human hepatic lipase and ApoE in transgenic rabbits attenuates response to dietary cholesterol and alters lipoprotein subclass distributions. Arterioscler. Thromb. Vasc. Biol. 1999, 19, 625-632. [CrossRef] [PubMed]

67. Hoeg, J.M.; Vaisman, B.L.; Demosky, S.J., Jr.; Meyn, S.M.; Talley, G.D.; Hoyt, R.F., Jr.; Feldman, S.; Berard, A.M.; Sakai, N.; Wood, D.; et al. Lecithin:cholesterol acyltransferase overexpression generates hyperalpha-lipoproteinemia and a nonatherogenic lipoprotein pattern in transgenic rabbits. J. Biol. Chem. 1996, 271, 4396-4402. [CrossRef] [PubMed]

68. Hoeg, J.M.; Santamarina-Fojo, S.; Berard, A.M.; Cornhill, J.F.; Herderick, E.E.; Feldman, S.H.; Haudenschild, C.C.; Vaisman, B.L.; Hoyt, R.F., Jr.; Demosky, S.J., Jr.; et al. Overexpression of lecithin:cholesterol acyltransferase in transgenic rabbits prevents diet-induced atherosclerosis. Proc. Natl. Acad. Sci. USA 1996, 93, 11448-11453. [CrossRef]

69. Serhan, C.N.; Jain, A.; Marleau, S.; Clish, C.; Kantarci, A.; Behbehani, B.; Colgan, S.P.; Stahl, G.L.; Merched, A.; Petasis, N.A.; et al. Reduced inflammation and tissue damage in transgenic rabbits overexpressing 15-lipoxygenase and endogenous anti-inflammatory lipid mediators. J. Immunol. 2003, 171, 6856-6865. [CrossRef]

70. Serhan, C.N. Clues for new therapeutics in osteoporosis and periodontal disease: New roles for lipoxygenases? Expert Opin. Ther. Targets 2004, 8, 643-652. [CrossRef]

71. Shen, J.; Herderick, E.; Cornhill, J.F.; Zsigmond, E.; Kim, H.S.; Kuhn, H.; Guevara, N.V.; Chan, L. Macrophage-mediated 15-lipoxygenase expression protects against atherosclerosis development. J. Clin. Investig. 1996, 98, 2201-2208. [CrossRef]

72. Kitajima, S.; Morimoto, M.; Liu, E.; Koike, T.; Higaki, Y.; Taura, Y.; Mamba, K.; Itamoto, K.; Watanabe, T.; Tsutsumi, K.; et al. Overexpression of lipoprotein lipase improves insulin resistance induced by a high-fat diet in transgenic rabbits. Diabetologia 2004, 47, 1202-1209. [CrossRef]

73. Fan, J.; Unoki, H.; Kojima, N.; Sun, H.; Shimoyamada, H.; Deng, H.; Okazaki, M.; Shikama, H.; Yamada, N.; Watanabe, T. Overexpression of lipoprotein lipase in transgenic rabbits inhibits diet-induced hypercholesterolemia and atherosclerosis. J. Biol. Chem. 2001, 276, 40071-40079. [CrossRef] [PubMed]

74. Ichikawa, T.; Liang, J.; Kitajima, S.; Koike, T.; Wang, X.; Sun, H.; Morimoto, M.; Shikama, H.; Watanabe, T.; Yamada, N.; et al. Macrophage-derived lipoprotein lipase increases aortic atherosclerosis in cholesterol-fed Tg rabbits. Atherosclerosis 2005, 179, 87-95. [CrossRef] [PubMed]

75. Niimi, M.; Nishijima, K.; Kitajima, S.; Matsuhisa, F.; Satoh, K.; Yamazaki, H.; Zhang, J.; Chen, Y.E.; Fan, J. Macrophage-derived matrix metalloproteinase-1 enhances aortic aneurysm formation in transgenic rabbits. J. Biomed. Res. 2019, 33, 271-279.

76. Chen, Y.; Waqar, A.B.; Nishijima, K.; Ning, B.; Kitajima, S.; Matsuhisa, F.; Chen, L.; Liu, E.; Zhang, J.; Chen, Y.E.; et al. Macrophage-derived MMP-9 enhances the vascular calcification and progression of atherosclerotic lesions in transgenic rabbits. J. Cell. Mol. Med. 2020, 24, 4261-4274. [CrossRef]

77. Wang, X.; Liang, J.; Koike, T.; Sun, H.; Ichikawa, T.; Kitajima, S.; Morimoto, M.; Shikama, H.; Watanabe, T.; Sasaguri, Y.; et al. Overexpression of human matrix metalloproteinase-12 enhances the development of inflammatory arthritis in transgenic rabbits. Am. J. Pathol. 2004, 165, 1375-1383. [CrossRef]

78. Fan, J.; Wang, X.; Wu, L.; Matsumoto, S.I.; Liang, J.; Koike, T.; Ichikawa, T.; Sun, H.; Shikama, H.; Sasaguri, Y.; et al. Macrophage-specific overexpression of human matrix metalloproteinase-12 in transgenic rabbits. Transgenic Res. 2004, 13, 261-269. [CrossRef]

79. Masson, D.; Deckert, V.; Gautier, T.; Klein, A.; Desrumaux, C.; Viglietta, C.; Pais de Barros, J.P.; Le Guern, N.; Grober, J.; Labbe, J.; et al. Worsening of diet-induced atherosclerosis in a new model of transgenic rabbit expressing the human plasma phospholipid transfer protein. Arterioscler. Thromb. Vasc. Biol. 2011, 31, 766-774. [CrossRef] 
80. Zhao, S.; Li, Y.; Gao, S.; Wang, X.; Sun, L.; Cheng, D.; Bai, L.; Guan, H.; Wang, R.; Fan, J.; et al. Autocrine Human Urotensin II Enhances Macrophage-Derived Foam Cell Formation in Transgenic Rabbits. Biomed. Res. Int. 2015, 2015, 843959. [CrossRef]

81. James, J.; Sanbe, A.; Yager, K.; Martin, L.; Klevitsky, R.; Robbins, J. Genetic manipulation of the rabbit heart via transgenesis. Circulation 2000, 101, 1715-1721. [CrossRef]

82. James, J.; Martin, L.; Krenz, M.; Quatman, C.; Jones, F.; Klevitsky, R.; Gulick, J.; Robbins, J. Forced expression of alpha-myosin heavy chain in the rabbit ventricle results in cardioprotection under cardiomyopathic conditions. Circulation 2005, 111, 2339-2346. [CrossRef] [PubMed]

83. Suzuki, T.; Palmer, B.M.; James, J.; Wang, Y.; Chen, Z.; VanBuren, P.; Maughan, D.W.; Robbins, J.; LeWinter, M.M. Effects of cardiac myosin isoform variation on myofilament function and crossbridge kinetics in transgenic rabbits. Circ. Heart Fail. 2009, 2, 334-341. [CrossRef] [PubMed]

84. Stanley, B.A.; Graham, D.R.; James, J.; Mitsak, M.; Tarwater, P.M.; Robbins, J.; Van Eyk, J.E. Altered myofilament stoichiometry in response to heart failure in a cardioprotective alpha-myosin heavy chain transgenic rabbit model. Proteomics Clin. Appl. 2011, 5, 147-158. [CrossRef] [PubMed]

85. Sanbe, A.; James, J.; Tuzcu, V.; Nas, S.; Martin, L.; Gulick, J.; Osinska, H.; Sakthivel, S.; Klevitsky, R.; Ginsburg, K.S.; et al. Transgenic rabbit model for human troponin I-based hypertrophic cardiomyopathy. Circulation 2005, 111, 2330-2338. [CrossRef]

86. Nishizawa, T.; Shen, Y.-T.; Rossi, F.; Hong, C.; Robbins, J.; Ishikawa, Y.; Sadoshima, J.; Vatner, D.E.; Vatner, S.F. Altered autonomic control in conscious transgenic rabbits with overexpressed cardiac Gsalpha. Am. J. Physiol. Heart Circ. Physiol. 2007, 292, H971-H975. [CrossRef]

87. Nishizawa, T.; Vatner, S.F.; Hong, C.; Shen, Y.-T.; Hardt, S.E.; Robbins, J.; Ishikawa, Y.; Sadoshima, J.; Vatner, D.E. Overexpressed cardiac Gsalpha in rabbits. J. Mol. Cell Cardiol. 2006, 41, 44-50. [CrossRef]

88. James, J.; Zhang, Y.; Wright, K.; Witt, S.; Glascock, E.; Osinska, H.; Klevitsky, R.; Martin, L.; Yager, K.; Sanbe, A.; et al. Transgenic rabbits expressing mutant essential light chain do not develop hypertrophic cardiomyopathy. J. Mol. Cell Cardiol. 2002, 34, 873-882. [CrossRef]

89. Pattison, J.S.; Waggoner, J.R.; James, J.; Martin, L.; Gulick, J.; Osinska, H.; Klevitsky, R.; Kranias, E.G.; Robbins, J. Phospholamban overexpression in transgenic rabbits. Transgenic Res. 2008, 17, 157-170. [CrossRef]

90. Marian, A.J.; Wu, Y.; Lim, D.S.; McCluggage, M.; Youker, K.; Yu, Q.T.; Brugada, R.; DeMayo, F.; Quinones, M.; Roberts, R. A transgenic rabbit model for human hypertrophic cardiomyopathy. J. Clin. Investig. 1999, 104, 1683-1692. [CrossRef]

91. Nagueh, S.F.; Kopelen, H.A.; Lim, D.S.; Zoghbi, W.A.; Quinones, M.A.; Roberts, R.; Marian, A.J. Tissue Doppler imaging consistently detects myocardial contraction and relaxation abnormalities, irrespective of cardiac hypertrophy, in a transgenic rabbit model of human hypertrophic cardiomyopathy. Circulation 2000, 102, 1346-1350. [CrossRef]

92. Lowey, S.; Bretton, V.; Joel, P.B.; Trybus, K.M.; Gulick, J.; Robbins, J.; Kalganov, A.; Cornachione, A.S.; Rassier, D.E. Hypertrophic cardiomyopathy R403Q mutation in rabbit beta-myosin reduces contractile function at the molecular and myofibrillar levels. Proc. Natl. Acad. Sci. USA 2018, 115, 11238-11243. [CrossRef] [PubMed]

93. Wakula, P.; Bisping, E.; Kockskamper, J.; Post, H.; Brauer, S.; Deuter, M.; Oehlmann, R.; Besenfelder, U.; Lai, F.A.; Brem, G.; et al. CMV promoter is inadequate for expression of mutant human RyR2 in transgenic rabbits. J. Pharmacol. Toxicol. Methods 2011, 63, 180-185. [CrossRef] [PubMed]

94. Brunner, M.; Peng, X.; Liu, G.X.; Ren, X.Q.; Ziv, O.; Choi, B.R.; Mathur, R.; Hajjiri, M.; Odening, K.E.; Steinberg, E.; et al. Mechanisms of cardiac arrhythmias and sudden death in transgenic rabbits with long QT syndrome. J. Clin. Investig. 2008, 118, 2246-2259. [CrossRef] [PubMed]

95. Odening, K.E.; Hyder, O.; Chaves, L.; Schofield, L.; Brunner, M.; Kirk, M.; Zehender, M.; Peng, X.; Koren, G. Pharmacogenomics of anesthetic drugs in transgenic LQT1 and LQT2 rabbits reveal genotype-specific differential effects on cardiac repolarization. Am. J. Physiol. Heart Circ. Physiol. 2008, 295, H2264-H2272. [CrossRef]

96. Hornyik, T.; Castiglione, A.; Franke, G.; Perez-Feliz, S.; Major, P.; Hiripi, L.; Koren, G.; Bosze, Z.; Varro, A.; Zehender, M.; et al. Transgenic LQT2, LQT5, and LQT2-5 rabbit models with decreased repolarisation reserve for prediction of drug-induced ventricular arrhythmias. Br. J. Pharmacol. 2020. [CrossRef] 
97. Major, P.; Baczko, I.; Hiripi, L.; Odening, K.E.; Juhasz, V.; Kohajda, Z.; Horvath, A.; Seprenyi, G.; Kovacs, M.; Virag, L.; et al. A novel transgenic rabbit model with reduced repolarization reserve: Long QT syndrome caused by a dominant-negative mutation of the KCNE1 gene. Br. J. Pharmacol. 2016, 173, $2046-2061$. [CrossRef]

98. Hu, J.; Peng, X.; Schell, T.D.; Budgeon, L.R.; Cladel, N.M.; Christensen, N.D. An HLA-A2.1-transgenic rabbit model to study immunity to papillomavirus infection. J. Immunol. 2006, 177, 8037-8045. [CrossRef]

99. Baranyi, M.; Cervenak, J.; Bender, B.; Kacskovics, I. Transgenic rabbits that overexpress the neonatal FC receptor $\left(\mathrm{F}_{\mathrm{C}} \mathrm{Rn}\right)$ generate higher quantities and improved qualities of anti-thymocyte globulin (ATG). PLoS ONE 2013, 8, e76839. [CrossRef]

100. Jasper, P.J.; Rhee, K.J.; Kalis, S.L.; Sethupathi, P.; Yam, P.C.; Zhai, S.K.; Knight, K.L. B lymphocyte deficiency in IgH-transgenic rabbits. Eur. J. Immunol. 2007, 37, 2290-2299. [CrossRef]

101. Snyder, B.W.; Vitale, J.; Milos, P.; Gosselin, J.; Gillespie, F.; Ebert, K.; Hague, B.F.; Kindt, T.J.; Wadsworth, S.; Leibowitz, P. Developmental and tissue-specific expression of human CD4 in transgenic rabbits. Mol.Reprod. Dev. 1995, 40, 419-428. [CrossRef]

102. Leno, M.; Hague, B.F.; Teller, R.; Kindt, T.J. HIV-1 mediates rapid apoptosis of lymphocytes from human CD4 transgenic but not normal rabbits. Virology 1995, 213, 450-454. [CrossRef]

103. Dunn, C.S.; Mehtali, M.; Houdebine, L.M.; Gut, J.P.; Kirn, A.; Aubertin, A.M. Human immunodeficiency virus type 1 infection of human CD4-transgenic rabbits. J. Gen. Virol. 1995, 76, 1327-1336. [CrossRef]

104. Taboit-Dameron, F.; Malassagne, B.; Viglietta, C.; Puissant, C.; Leroux-Coyau, M.; Chereau, C.; Attal, J.; Weill, B.; Houdebine, L.M. Association of the 5'HS4 sequence of the chicken beta-globin locus control region with human EF1 alpha gene promoter induces ubiquitous and high expression of human CD55 and CD59 cDNAs in transgenic rabbits. Transgenic Res. 1999, 8, 223-235. [CrossRef] [PubMed]

105. Peng, X.; Olson, R.O.; Christian, C.B.; Lang, C.M.; Kreider, J.W. Papillomas and carcinomas in transgenic rabbits carrying EJ-ras DNA and cottontail rabbit papillomavirus DNA. J. Virol. 1993, 67, 1698-1701. [CrossRef] [PubMed]

106. Peng, X.; Griffith, J.W.; Han, R.; Lang, C.M.; Kreider, J.W. Development of keratoacanthomas and squamous cell carcinomas in transgenic rabbits with targeted expression of EJras oncogene in epidermis. Am. J. Pathol. 1999, 155, 315-324. [CrossRef]

107. Knight, K.L.; Spieker-Polet, H.; Kazdin, D.S.; Oi, V.T. Transgenic rabbits with lymphocytic leukemia induced by the c-myc oncogene fused with the immunoglobulin heavy chain enhancer. Proc. Natl. Acad. Sci. USA 1988, 85, 3130-3134. [CrossRef]

108. Sethupathi, P.; Spieker-Polet, H.; Polet, H.; Yam, P.C.; Tunyaplin, C.; Knight, K.L. Lymphoid and non-lymphoid tumors in E kappa-myc transgenic rabbits. Leukemia 1994, 8, 2144-2155.

109. Costa, C.; Solanes, G.; Visa, J.; Bosch, F. Transgenic rabbits overexpressing growth hormone develop acromegaly and diabetes mellitus. FASEB J. 1998, 12, 1455-1460. [CrossRef]

110. Takahashi, R.-i.; Kuramochi, T.; Aoyagi, K.; Hashimoto, S.; Miyoshi, I.; Kasai, N.; Hakamata, Y.; Kobayashi, E.; Ueda, M. Establishment and characterization of CAG/EGFP transgenic rabbit line. Transgenic Res. 2007, 16, 115-120. [CrossRef]

111. Yin, M.; Fang, Z.; Jiang, W.; Xing, F.; Jiang, M.; Kong, P.; Li, Y.; Zhou, X.; Tang, L.; Li, S.; et al. The Oct4 promoter-EGFP transgenic rabbit: A new model for monitoring the pluripotency of rabbit stem cells. Int. J. Dev. Biol. 2013, 57, 845-852. [CrossRef]

112. Sarradin, P.; Viglietta, C.; Limouzin, C.; Andreoletti, O.; Daniel-Carlier, N.; Barc, C.; Leroux-Coyau, M.; Berthon, P.; Chapuis, J.; Rossignol, C.; et al. Transgenic Rabbits Expressing Ovine PrP Are Susceptible to Scrapie. PLoS Pathog. 2015, 11, e1005077. [CrossRef] [PubMed]

113. Kondo, M.; Sakai, T.; Komeima, K.; Kurimoto, Y.; Ueno, S.; Nishizawa, Y.; Usukura, J.; Fujikado, T.; Tano, Y.; Terasaki, H. Generation of a transgenic rabbit model of retinal degeneration. Invest. Ophthalmol. Vis. Sci. 2009, 50, 1371-1377. [CrossRef] [PubMed]

114. Kitajima, S.; Liu, E.; Morimoto, M.; Koike, T.; Yu, Y.; Watanabe, T.; Imagawa, S.; Fan, J. Transgenic rabbits with increased VEGF expression develop hemangiomas in the liver: A new model for Kasabach-Merritt syndrome. Lab. Invest. 2005, 85, 1517-1527. [CrossRef] [PubMed]

115. Liu, E.; Morimoto, M.; Kitajima, S.; Koike, T.; Yu, Y.; Shiiki, H.; Nagata, M.; Watanabe, T.; Fan, J. Increased expression of vascular endothelial growth factor in kidney leads to progressive impairment of glomerular functions. J. Am. Soc. Nephrol. 2007, 18, 2094-2104. [CrossRef] [PubMed] 
116. Vidal, E.; Fernandez-Borges, N.; Pintado, B.; Erana, H.; Ordonez, M.; Marquez, M.; Chianini, F.; Fondevila, D.; Sanchez-Martin, M.A.; Andreoletti, O.; et al. Transgenic Mouse Bioassay: Evidence That Rabbits Are Susceptible to a Variety of Prion Isolates. PLoS Pathog. 2015, 11, e1004977. [CrossRef]

117. Marian, A.J. On mice, rabbits, and human heart failure. Circulation 2005, 111, 2276-2279. [CrossRef]

118. Janne, J.; Alhonen, L.; Hyttinen, J.M.; Peura, T.; Tolvanen, M.; Korhonen, V.P. Transgenic bioreactors. Biotechnol. Annu. Rev. 1998, 4, 55-74.

119. Ziomek, C.A. Commercialization of proteins produced in the mammary gland. Theriogenology 1998, 49, 139-144. [CrossRef]

120. Vicente, J.S.; Viudes-de-Castro, M.P. A sucrose-DMSO extender for freezing rabbit semen. Reprod. Nutr. Dev. 1996, 36, 485-492. [CrossRef]

121. Dalimata, A.M.; Graham, J.K. Cryopreservation of rabbit spermatozoa using acetamide in combination with trehalose and methyl cellulose. Theriogenology 1997, 48, 831-841. [CrossRef]

122. Nishijima, K.; Kitajima, S.; Koshimoto, C.; Morimoto, M.; Watanabe, T.; Fan, J.; Matsuda, Y. Motility and fertility of rabbit sperm cryopreserved using soybean lecithin as an alternative to egg yolk. Theriogenology 2015, 84, 1172-1175. [CrossRef] [PubMed]

123. Kasai, M.; Hamaguchi, Y.; Zhu, S.E.; Miyake, T.; Sakurai, T.; Machida, T. High survival of rabbit morulae after vitrification in an ethylene glycol-based solution by a simple method. Biol. Reprod. 1992, 46, 1042-1046. [CrossRef] [PubMed]

124. Marco-Jimenez, F.; Jimenez-Trigos, E.; Almela-Miralles, V.; Vicente, J.S. Development of Cheaper Embryo Vitrification Device Using the Minimum Volume Method. PLoS ONE 2016, 11, e0148661. [CrossRef] [PubMed]

125. Al-Hasani, S.; Hepnar, C.; Diedrich, K.; van der Ven, H.; Krebs, D. Cryopreservation of rabbit zygotes. Hum. Reprod. 1992, 7 (Suppl. 1), 81-83. [CrossRef] [PubMed]

Publisher's Note: MDPI stays neutral with regard to jurisdictional claims in published maps and institutional affiliations. 